\title{
Genetic variation in wild populations and farmed stocks of Nile tilapia (Oreochromis niloticus) in Madagascar
}

\author{
Monique Ravakarivelo ${ }^{1,2}$ Elodie Pepey ${ }^{3,4}$ John A. H. Benzie ${ }^{5,6}$ \\ Noromalala Raminosoa ${ }^{1}$ Harentsoaniaina Rasamoelina ${ }^{1}$ \\ Olivier Mikolasek ${ }^{3,4}$ Hugues de Verdal ${ }^{3,4,6^{*}}$
}

\section{Keywords}

Oreochromis niloticus, fish, tilapia, animal population, genetic variation, genetic structures, Madagascar

\section{Submitted: 7 June 2018}

Accepted: 5 September 2019

Published: 30 September 2019

DOI: 10.19182/remvt.31780

\begin{abstract}
Summary
Four farmed stocks and four wild populations of Nile tilapia (Oreochromis niloticus), which was first introduced to Madagascar sixty years ago, were assayed for genetic variation at nine microsatellite loci to determine levels of genetic diversity within populations and genetic relationships between them. Allelic diversity overlapped with that found in previously sampled populations elsewhere in Africa. There was no evidence of deviations from allele frequencies expected under conditions of Hardy-Weinberg equilibrium or of inbreeding in studied populations. Three distinct clusters of genotypes provided evidence of three separate introductions (from Egypt and Mauritius in 1956, and from Japan in 2011), and the occurrence of genotypes from more than one cluster within a single population provided evidence of their mixing. There were significant differences between populations which were not from the same environment (wild or farmed) or were not geographically related. Wild populations may be a valuable resource to support further development of farmed stocks from the perspective of genetic diversity.
\end{abstract}

- How to quote this article: Ravakarivelo M., Pepey E., Benzie J.A.H., Raminosoa N., Rasamoelina H., Mikolasek O., de Verdal H., 2019. Genetic variation in wild populations and farmed stocks of Nile tilapia (Oreochromis niloticus) in Madagascar. Rev. Elev. Med. Vet. Pays Trop., 72 (3): 101-106, doi: $10.19182 /$ remvt.31780

\section{INTRODUCTION}

Nile tilapia, Oreochromis niloticus, is the second most frequently farmed fish worldwide after carps (FAO, 2014). World production is expected to attain 7.3 million tons a year in 2030 (FAO, 2014) with a market value of around 5 billion USD. Nile tilapia was introduced to Madagascar in 1956 from Egypt and Mauritius (Kiener, 1963; Moreau, 1988). Wild populations of this species were rapidly established and are now widely spread in natural lakes and rivers. Nile

1. FOFIFA, DRZVP, Ampandrianomby, Antananarivo, Madagascar.

2. Department of Animal Biology, University of Antananarivo, Antananarivo, Madagascar.

3. CIRAD, UMR ISEM, TA B-116/16, 73 rue Jean-François Breton,

34398 Montpellier Cedex 5, France.

4. SEM, Univ Montpellier, CNRS, EPHE, IRD, Montpellier, France.

5. School of Biological Earth and Environmental Sciences, University College Cork, Cork Ireland.

6. Worldfish, Jalan Batu Maung, Bayan Lepas, Penang, Malaysia.

* Corresponding author

Tel.: +33467614467; email: hugues.de_verdal@cirad.fr tilapia has become one of the major fish species consumed in the country.

Although freshwater aquaculture in Madagascar is dominated by carps and tilapias, production has remained low (3763 tons, FAO, 2010-2019). One possible contributory factor to the low production is the potential low genetic variability and inbreeding in the wild populations themselves or in the farmed stocks derived from them, or both. In the past, although large numbers of fish may have been introduced, their genetic diversity was unknown and potentially limited. In addition, a small number of fish is used as breeders to develop the founder stock in individual farms in Madagascar. These practices are known to reduce genetic variability, increase inbreeding and thus reduce fish growth performance (Chevassus, 1989; Ferguson et al., 1985).

Rakotoambinima et al. (2009) noted the importance of estimating the genetic variability of this species about 50 years after its introduction and checking the relationships between wild and farmed fish. Estimates of genetic diversity are essential to manage the biodiversity of local resources (Beaumont and Hoare, 2003; Romana-Eguia et al., 2005 ) and are required to assess the soundness (sufficient variability and lack of inbreeding) of the stocks for the development of aquaculture (Desvignes et al., 2001; Thai et al., 2006). In the last decade 
authorities and fish farmers increased genetic mixing through exchanges of breeders between farms and controlled restocking in different locations, in attempts to avoid diversity reduction and inbreeding. New strains of Nile tilapias were also introduced in 2011 and 2013 from Japan and Thailand, respectively, with a production objective. To date, however, there has been no direct measurement of the genetic variability of wild and farmed stocks.

The aims of the present study were 1) to assess the genetic structure of wild populations and farmed stocks of Nile tilapia using microsatellites to understand the present genetic diversity of Nile tilapia in Madagascar, and 2) to assess whether the inbreeding levels could affect fish farming development of this species in the country.

\section{MATERIALS AND METHODS}

\section{Samples}

A total of 306 samples from wild populations and farmed stocks were collected between 2011 and 2012 from eight locations in seven regions in Madagascar (ALA: Alaotra Mangoro; ANA: Analamanga; ATS: Atsimo-Andrefana; BOE: Boeny; BON: Bongolava; ITA: Itasy; VAK: Vakinankaratra) (Figure 1). Fish were sampled from four farms maintaining breeding stock, and from natural locations known to have wild populations. Although we aimed at sampling 50 fish per location, the low number of fish available at some sites and the difficulties met with in tissue preservation explained the lower sample sizes obtained for some populations (Table I). A small piece of dorsal fin was cut from each individual fish sampled, stored in $95 \%$ ethanol and exported to France for DNA analyses.

\section{DNA extraction}

Genomic DNA extraction was performed at the French Agricultural Research Centre for International Development (CIRAD), Montpellier, France, with two commercial kits. Genomic DNA from ALA, ITA wild (ITAw), ITA farmed (ITAf), VAK and ANA populations was extracted using Chelex 100 resin extraction kit (Bio-Rad, France) as a rapid and simple technique for extracting DNA with a reduced potential

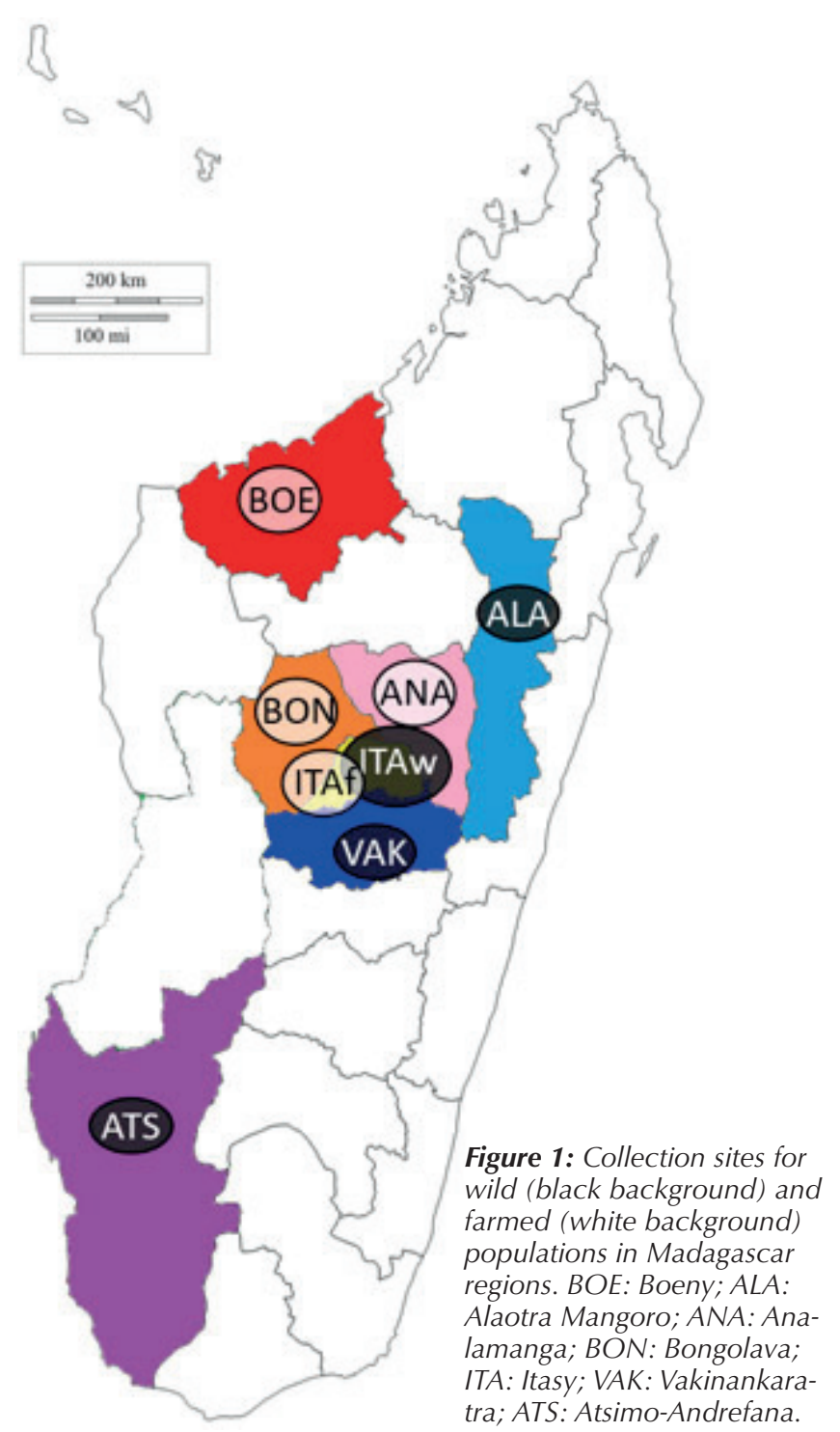

Table I

Sample size (n), average number of alleles per locus (A), number of private alleles per population (pA), observed heterozygosity $\left(\mathrm{H}_{0}\right)$, expected heterozygosity $\left(\mathrm{H}_{\mathrm{E}}\right)$ and inbreeding coefficient $\left(\mathrm{F}_{\mathrm{IS}}\right)$ based on the average of nine polymorphic microsatellite loci for eight Nile tilapia populations in Madagascar

\begin{tabular}{|c|c|c|c|c|c|c|c|}
\hline Population & $\mathbf{n}$ & A & pA & $\mathbf{H}_{0}$ & $\mathrm{H}_{\mathrm{E}}$ & $\mathrm{H}_{0} / \mathrm{H}_{\mathrm{E}}$ & $\mathrm{F}_{\mathrm{IS}}$ \\
\hline \multicolumn{8}{|l|}{ Farmed } \\
\hline BOE & 27 & 3.78 & 7 & 0.54 & 0.55 & 0.98 & -0.16 \\
\hline ANA & 25 & 5.22 & 1 & 0.67 & 0.70 & 0.95 & 0.07 \\
\hline BON & 24 & 5.22 & 2 & 0.58 & 0.64 & 0.90 & 0.25 \\
\hline ITAf & 50 & 8.78 & 17 & 0.69 & 0.74 & 0.93 & 0.05 \\
\hline Mean & 31.5 & 5.75 & 6.75 & 0.62 & 0.66 & 0.94 & 0.05 \\
\hline \multicolumn{8}{|l|}{ Wild } \\
\hline ALA & 50 & 5.44 & 4 & 0.49 & 0.49 & 0.99 & -0.18 \\
\hline ITAw & 50 & 8.89 & 29 & 0.66 & 0.77 & 0.86 & 0.03 \\
\hline VAK & 50 & 3.33 & 1 & 0.55 & 0.54 & 1.02 & 0.04 \\
\hline ATS & 30 & 4.56 & 4 & 0.59 & 0.59 & 1.00 & -0.06 \\
\hline Mean & 45 & 5.56 & 9.5 & 0.57 & 0.60 & 0.97 & -0.04 \\
\hline
\end{tabular}

Populations in each group are listed from the most northern to the most southern sites. BOE: Boeny; ANA: Analamanga; BON: Bongolava; ITA: Itasy; ALA: Alaotra Mangoro; VAK: Vakinankaratra; ATS: Atsimo-Andrefana; w: wild; f: farmed; $\mathrm{H}_{0} / \mathrm{H}_{\mathrm{E}}$ and $\mathrm{F}_{\mathrm{IS}}$ are not significantly different from 1 and 0 , respectively. 
for contamination given the low number of steps and reagents added (Walsh et al., 1991; Musapa et al., 2013). Fin clip samples were placed in 96 well plates with $150 \mu \mathrm{l}$ of Chelex solution at $5 \%$ already prepared and stirred. Then $150 \mu$ l of TE buffer 1X (containing Tris EDTA) was added to each well followed by $10 \mu \mathrm{l}$ of proteinase $\mathrm{K}$ at $10 \mathrm{mg}^{-\mathrm{ml}^{-1}}$. Plates were incubated in a thermocycler for $2 \mathrm{~h}$ at $55^{\circ} \mathrm{C}$, then $10 \mathrm{~min}$ at $96^{\circ} \mathrm{C}$ according to the manufacturer's instructions. However, the DNA in some samples was degraded and that from ATS, BON and BOE populations was extracted using Wizard Genomic DNA purification kit (Promega, USA) according to the manufacturer's instructions. After extraction with either technique, the DNA was stored at $-20^{\circ} \mathrm{C}$ until processing.

\section{Microsatellite analyses}

The polymerase chain reaction (PCR) was used to amplify DNA fragments containing microsatellites that differed in number repetitions of the repeated motifs. The nine microsatellites used were developed from the Oreochromis niloticus genomic DNA library produced by Lee and Kocher (1996) (Supplementary Material I).

Genotypes were obtained by PCR amplification with indirect fluorescent tagging (Schuelke, 2000; Bezault et al., 2011). With this approach, for each locus the F primer was elongated in his 5' extremity by a 19 base-pair (bp) M13 sequence (5'-CACGACGTTGTAAAACGAC-3') and a primer labeled with appropriate fluorescent dyes, specific to the M13 sequence, was also incorporated to the PCR reaction.

The PCR amplification was performed in a $20-\mu$ reaction volume containing $25 \mathrm{ng}$ of template DNA, $80 \mathrm{nM}$ of F primer, $100 \mathrm{nM}$ of R primer, $0.1 \mathrm{pM}$ IRDye 700 or 8000 -labeled universal M13 primer, $2 \mathrm{mM}$ of dNTPs, $0.5 \mathrm{U}$ of Taq DNA polymerase, $2 \mu \mathrm{l}$ of $10 \mathrm{X}$ reaction buffer $(10 \mathrm{mM}$ Tris- $\mathrm{HCl} \mathrm{pH} 9,50 \mathrm{mM} \mathrm{KCl}, 1.5 \mathrm{mM} \mathrm{MgCl} 2,0.1 \%$ Triton X100, $0.2 \mathrm{mg} / \mathrm{ml}$ BSA). The same composition of the PCR mixture was used in amplification of all microsatellites investigated in the present study.

Thermal cycling conditions consisted of enzyme activation at $94^{\circ} \mathrm{C}$ for $5^{\circ} \mathrm{C}$, followed by 10 cycles of touchdown starting at the annealing temperature $+5^{\circ} \mathrm{C}$ with a decrease of $0.5^{\circ} \mathrm{C}$ at each cycle during 10 cycles. Then 30 cycles of amplification were done with the annealing temperature, specific for each couple of primers. A final extension step was performed at $72^{\circ} \mathrm{C}$ for $10 \mathrm{~min}$, followed by a final hold at $15^{\circ} \mathrm{C}$.

Samples were run on 7\% denaturing acrylamide gel using 4300 DNA Analyzer LI-COR (Li-color Bioscience, USA). Allele size was estimated using SAGA GT Client Software (Li-color Bioscience) by comparing the samples to molecular weight standards (from 71 to $363 \mathrm{bp}$ ).

\section{Data analyses}

The number of alleles, observed and expected heterozygosity (Nei, 1987) were calculated for each population using GENEPOP software (version 4.1, Rousset 2008). The Hardy-Weinberg equilibrium was tested using GENEPOP. Alleles were classified as private alleles when they were observed only in one population. The same software was used to determine the proportion of genetic variation partitioned among populations $\left(\mathrm{F}_{\mathrm{ST}}\right)$. Arlequin software (version 3.5, Excoffier and Lischer, 2010) was used to determine the proportion of genetic variation partitioned within populations $\left(\mathrm{F}_{\mathrm{IS}}\right)$. Mann-Whitney tests were used to compare the results of wild populations and farmed stocks.

To identify different genetic subgroups and to infer the genetic ancestry of individual animals to a given population, multi-locus genotypes were analyzed by a model-based clustering algorithm with the Structure 2.3.4 software (Pritchard and Donnelly, 2000; Falush et al., 2007). Twenty runs of Structure were performed for each K from 1 to 8 (the total number of populations sampled). We used 100,000 iterations of the Gibbs sampler after a burn-in of 50,000 iterations. To estimate the posterior probability of K, the method developed by Evanno et al. (2005) was followed, plotting values of $\operatorname{LnP}(\mathrm{D})$ (the log probability of data) for each $K$ and estimating the delta $K(\Delta K)$ statistics, based on the rate of change in $\mathrm{LnP}(\mathrm{D})$ between two successive $\mathrm{K}$ values.

\section{RESULTS}

\section{Genetic diversity}

Estimates of microsatellite variations in the eight Nile tilapia populations $(n=306)$ are presented in Table I. The average number of alleles per locus ranged from 3.33 to 8.89 and was not significantly different between wild populations and farmed stocks. In the same way, the number of private alleles was not significantly different between wild populations and farmed stocks. Wild populations and farmed stocks from Itasy, ITAw and ITAf, respectively, showed a higher number of private alleles than the other populations.

Among the eight populations collected, observed heterozygosity was the lowest in ALA (0.49) and the highest in ITAf (0.69). In every population, observed and expected heterozygosities were not significantly different when the average across microsatellite loci was considered, which indicates general conformation to expectations of Hardy-Weinberg equilibrium. Individual loci did not show deviation from Hardy-Weinberg equilibrium (data not shown). Globally, there were no significant differences between the observed heterozygosities in wild populations and farmed stocks. $\mathrm{F}_{\mathrm{IS}}$ estimated for each population was not significantly different from zero, indicating that none of the eight populations collected had significant inbreeding.

\section{Population structure}

Significant population differentiation was observed at the global level, with $17.7 \%$ of overall genetic variation attributed to differences between populations (i.e. $\mathrm{F}_{\mathrm{ST}}$ ). Population pairwise $\mathrm{F}_{\mathrm{ST}}$ ranged from 0.038 to 0.379 (Table II). BOE population showed high differentiation from all the other populations, with $\mathrm{F}_{\mathrm{ST}}$ values ranging from 0.225 to 0.379 . The wild ALA population was differentiated from the other three wild populations with $\mathrm{F}_{\mathrm{ST}}$ values ranging from 0.201 to 0.335 . A moderate differentiation was estimated between the farmed BON stock and three of the wild populations (not ITAw).

There was no indication showing that the farmed stocks as a group were more differentiated from the wild populations as a group than

\section{Table II}

Pairwise genetic variation $\left(\mathrm{F}_{\mathrm{ST}}\right)$ values between sites sampled for Nile tilapia in Madagascar

\begin{tabular}{lllllllll}
\multicolumn{3}{c}{} & \multicolumn{3}{c}{ Farm } & & \multicolumn{4}{c}{ Wild } \\
\cline { 2 - 4 } \cline { 5 - 8 } & ANA & BON & ITAf & & ALA & ITAw & VAK & ATS \\
\hline BOE & 0.264 & 0.291 & 0.225 & 0.379 & 0.243 & 0.364 & 0.301 \\
ANA & & 0.040 & 0.038 & 0.168 & 0.033 & 0.108 & 0.105 \\
BON & & & 0.068 & 0.188 & 0.085 & 0.168 & 0.161 \\
ITAf & & & & 0.098 & 0.076 & 0.169 & 0.151 \\
\hline ALA & & & & & 0.201 & 0.335 & 0.316 \\
ITAw & & & & & & 0.114 & 0.101 \\
VAK & & & & & & & & 0.190
\end{tabular}

Populations in each group are listed from the most northern to the most southern sites. BOE: Boeny; ANA: Analamanga; BON: Bongolava; ITA: Itasy; ALA: Alaotra Mangoro; VAK: Vakinankaratra; ATS: Atsimo-Andrefana; w: wild; f: farmed 
populations within each group. If anything, the wild populations showed more differentiation from each other than the farmed stocks.

The graph of $\mathrm{LnP}(\mathrm{D})$ did not show a clear point of change in the slope for any specific $\mathrm{K}$ value although minor changes in the slope were visible between $K=3$ and $K=4$ (Figure $2 A$ ). The distribution of $\Delta K$ clearly detected one peak at $\mathrm{K}=3$, suggesting a higher level of hierarchy at this $\mathrm{K}$ (Figure 2B). The structure pattern analyzed for $\mathrm{K}=3$ showed that the BOE population was composed of genotypes from one genetic group (light gray), differentiated from a second genetic group (gray) found in the majority of populations, and a third group of genotypes most commonly found in ALA and part of ITAf populations (dark gray) (Figure 3). Genotypes with other than $90 \%$ probability of being assigned to one genetic group may indicate a degree of introgression between the three genetic groups.

\section{DISCUSSION}

\section{Wild populations}

None of the individual populations showed a deviation from Hardy-Weinberg equilibrium or evidence of inbreeding, suggesting the wild populations had reached an equilibrium (if they ever departed from it). The introduction of Nile tilapia in 1956 also appears to have resulted in wild populations, which today have comparable heterozygosities and allelic diversities as other wild African tilapia populations (Bezault et al., 2011; Ndiwa et al., 2014). Mwanja et al. (2010) and Angienda et al. (2011) on introduced Nile tilapia in Victoria Lake, and Gu et al. (2014) on Chinese wild populations estimated the genetic structure and gene flow of wild Nile tilapia populations. They found for $O$. niloticus a number of alleles per locus ranging from 3.8 to 8.4 , an observed heterozygosity ranging from 0.31 to 0.80 , and low inbreeding $\left(\mathrm{F}_{\mathrm{IS}}\right)$ ranging from -0.10 to 0.28 . These results are in the same range as those of the present estimations, with on average 5.7 alleles per locus, 0.60 observed heterozygosity and -0.04 inbreeding.

Although neither the number of fish introduced at specific times nor details on their genetic constitution (e.g. number of families, number of populations included in the transfer) were known, there were multiple introductions. This, and subsequent mixing of those populations, including that deliberately undertaken in the last few years, may have resulted in genetic diversity in individual wild populations not very far from what is found in other wild populations.

The population structure analysis distinguished three clusters which may reflect the three known introductions of Nile tilapia in Madagascar (two in 1956 and one in 2011). Thai strains were introduced in 2013, after the sampling for this study was completed. There was evidence of mixing of the three different genetic groupings including that of the latest introduction with the others (e.g. in ITAw and ITAf) and those populations showed high allelic diversity. However, much of this high allelic diversity was associated with high diversity of private alleles. Other populations with less evidence of mixing showed measures of genetic diversity equivalent to other stocks. This suggested that the original introductions must have had a relatively adequate level of genetic diversity.

The relatively low differentiation between many of the wild populations (estimated by the pairwise $\mathrm{F}_{\mathrm{ST}}$ ) could be hypothesized by a potential origin of the Mauritius strain from Egypt. There is no available data to our knowledge to assess this hypothesis. The differences between the wild populations did not appear to be related to the degree of geographical separation of the populations. For example, ITAw showed more differences with ALA although it was closer geographically than ATS, with which it had less differences. It is more likely that the levels of differentiation reflected the predominant origins of the source populations rather than the influence of any other factor.
A

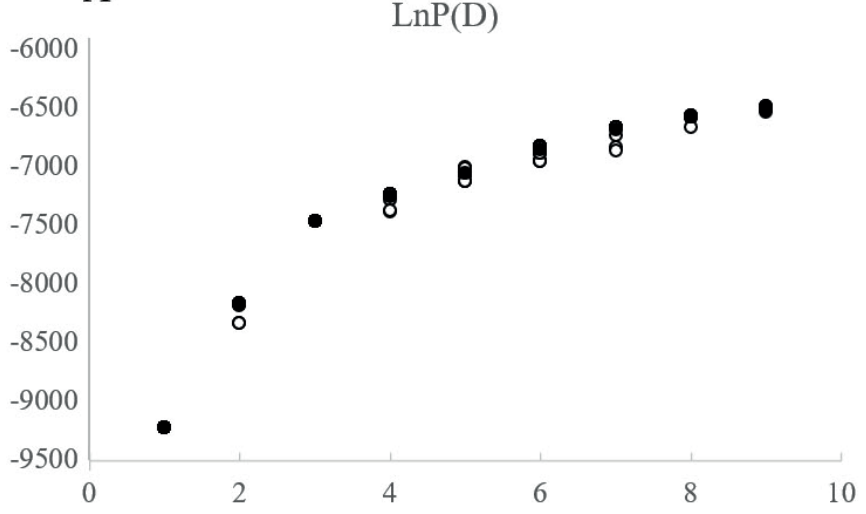

B

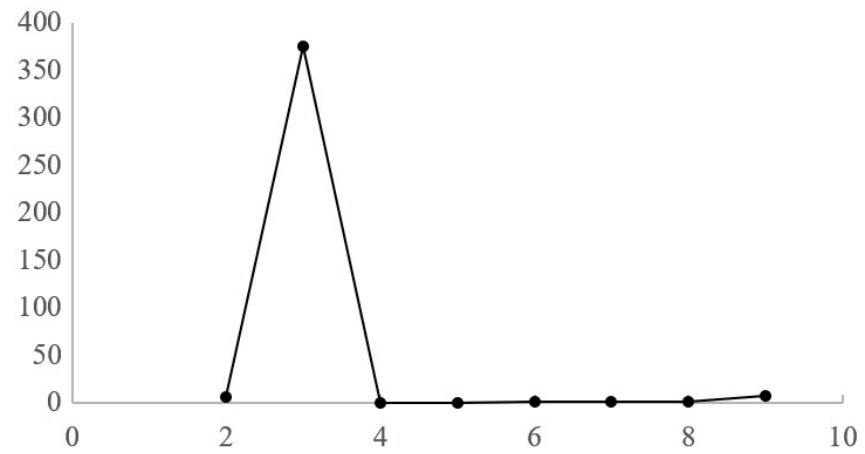

Figure 2: Uppermost hierarchical structure of Nile tilapia in Madagascar based on $\Delta K$. A) Estimated likelihood, $\operatorname{LnP(D)}$ for values of $K$ ranged from one to eight. The mean $\operatorname{LnP}(D)$ for each K over 20 runs were represented by a dark circle and each value of the 20 runs by a white circle. B) $\Delta K$ calculated as Evanno et al. (2005).

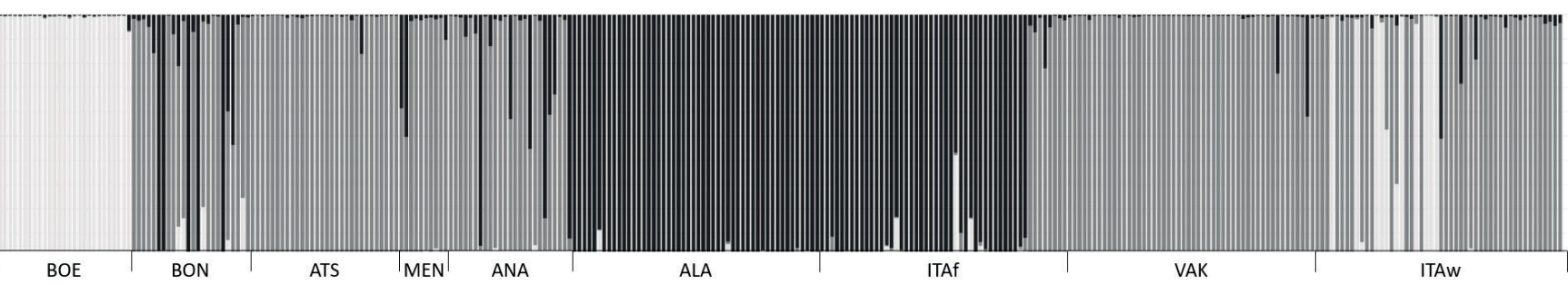

Figure 3: Clustering assignment of the eight Nile tilapia populations samples from Madagascar using STRUCTURE with $K=3$. Each color (light gray, gray and dark gray) represents one cluster. Each vertical line represents one individual, and each color for each line represents the membership probability of an individual to a given cluster. 


\section{Farmed stocks}

According to Oswald et al. (2016), there are three main types of tilapia farmers in Madagascar. The first type includes small scale farmers who represent the majority of tilapia farmers in the country. They have only one pond for reproduction and grow-out, and mainly use fish for personal consumption. There is generally no management of the strain, and exchanges between farmers are scant. Farmers harvest their fish regularly, sell the biggest fish and stock the smallest back to the pond. The second type includes farmers who have different ponds for reproduction and grow-out. Fry are produced throughout the hot season and sold to grow-out farmers or kept in grow-out ponds. The third type includes farmers specializing in fry production. They have an agreement to produce $100 \%$ male fry by hormonal inversion. They produce most of the fry used in aquaculture, which are transported over long distances to ponds and cages in lakes. These practices generate a high level of exchange between farms, and between farmed stocks and wild populations. This is due to escapees but also to relatively frequent captures of wild populations to renew the breeders used on farms.

It is important to note that only the biggest Nile tilapia farms were sampled in the present study. None of the small-scale farms were collected because of logistical reasons. This could bias the conclusions but the larger farms that maintain a separate broodstock population are more likely than either of the other two to show differentiation from wild populations, as they usually capture less wild fish for broodstock than the other two types. It would be interesting to increase the number of sample locations to have a broader view of the genetic diversity of the Nile tilapia in different farming systems in Madagascar.

As a consequence of this sampling choices, the fish sampled from the farms also showed no deviation of allele frequencies from that expected under conditions of Hardy-Weinberg Equilibrium or high signs of inbreeding indicating that they were either adequately managed or that insufficient time had elapsed for inbreeding to develop. These processes would explain the lack of significant genetic differences between most farmed stocks and wild populations.

Fish sampled from BOE farm showed a marked differentiation from the other farmed stocks which reflects the recent introduction (2011) of the population on that farm from Japan. Material has been sent from that farm to others and to the wild, which is reflected in individual fish being allocated to the BOE genotype group in ITAf and ITAw. The lack of differentiation between most of the farmed stocks and all the wild populations probably shows that farmers use wild populations for their farms and exchange fish among themselves. It is interesting to note that in wild population ITAw (from Itasy Lake) some fish were grouped in the same cluster as BOE, representing fish introduced from Japan in 2011. These results point to the high probability that fish from BOE were stocked in cages in Itasy Lake, and that escapees occurred or larvae from BOE hatcheries were used for restocking in Itasy Lake.

\section{CONCLUSION}

A comprehensive assessment of the multiple impediments to aquaculture growth and a comprehensive industry strategy are needed in order to fulfill the potential of this growing sector. The present results highlight that wild and domestic populations are relatively close genetically. As a consequence, the wild population could be a good resource for those facing diversity loss and/or inbreeding in some domestic stocks.

The extent to which wild populations performance is satisfactory with respect to production traits such as growth remains to be evaluated. Growth trials should evaluate the performance of Nile tilapia in different rearing environments, given that relatively high-altitude sites in Madagascar, where temperatures can be cold in winter, are markedly different from lowland sites. These trials may require a breeding program including traits for cold tolerance, or another species of tilapia, e.g. O. mossambicus and $O$. macrochir have already been introduced in Madagascar (Oswald et al., 2016).

\section{Acknowledgments}

The authors are most grateful to the Great Regional Technical Platform (GPTR) core facility for its technical support, especially to R. Rivallan (UMR AGAP, CIRAD) for his laboratory assistance during the experiments with the Li-Cor gel sequencer.

\section{Author contributions statement}

MR, NR, HR, OM, EP and HdV designed the experiment, MR, NR, HR collected the samples, MR and EP analyzed the samples, MR, EP and HdV performed statistical analyses and drafted the article, JAHB and $\mathrm{OM}$ revised the article. All the authors approved the manuscript.

\section{REFERENCES}

Angienda P.O., Lee H.J., Elmer K.R., Abila R., Waindi E.N., Meyer A., 2011. Genetic structure and gene flow in an endangered native tilapia fish (Oreochromis esculentus) compared to invasive Nile tilapia (Oreochromis niloticus) in Yala swamp, East Africa. Conserv. Genet., 12: 243-255, doi: 10.1007/s10592-010-0136-2

Beaumont R.A., Hoare K., 2003. Biotechnology and genetics in fisheries and aquaculture. Blackwell Science, Oxford, UK, 202 p., doi: $10.1002 / 9780470995198$

Bezault E., Balaresque P., Toguyeni A., Fermon Y., Araki H., Baroiller J.-F., Rognon X., 2011. Spatial and temporal variation in population genetic structure of wild Nile tilapia (Oreochromis niloticus) across Africa. BMC Genet., 12: 102, doi: 10.1186/1471-2156-12-102

Chevassus B., 1989. Aspects génétiques de la constitution de populations d'élevage destinées au repeuplement. Bull. Fr. Pêche Piscic., 314 : 146168, doi : 10.1051/kmae:1989010

Desvignes J.F., Laroche J., Durand J.D., Bouvet Y., 2001. Genetic variability in reared stocks of common carp (Cyprinus carpio L.) based on allozymes and microsatellites. Aquaculture, 194: 291-301, doi: 10.1016/s00448486(00)00534-2

Evanno G., Regnaut S., Goudet J., 2005. Detecting the number of clusters of individuals using the software STRUCTURE: a simulation study. Mol. ECol., 14: 2611-2620, doi: 10.1111/j.1365-294x.2005.02553.x

Excoffier L., Lischer H.E.L., 2010. Arlequin suite vers. 3.5: A new series of programs to perform population genetics analyses under Linux and Windows. Mol. Ecol. Resour., 10: 564-567, doi: 10.1111/j.1755-0998.2010.02847.x

Falush D., Stephens M., Pritchard J.K., 2007. Inference of population structure using multilocus genotype data: dominant markers and null alleles. Mol. Ecol. Notes, 7: 574-578, doi: 10.1111/j.1471-8286.2007.01758.x

FAO, 2014. The state of world fisheries and aquaculture. FAO, Rome, Italy

FAO, 2010-2019. Fisheries Global Information System (FAO-FIGIS). FAO Fisheries and Aquaculture Department, Rome, Italy (www.fao.org/fishery/)

Ferguson M.M., Danzmann R.G., Allendorf F.W., 1985. Developmental divergence among hatchery strains of rainbow trout (Salmo gairdneri). I. Pure strains. Can. J. Genet. Cytol., 27: 289-297, doi: 10.1139/g85-043

Gu D., Mu X., Song H., Luo D., Xu M., Luo J., Hu Y., 2014. Genetic diversity of invasive Oreochromis sp. (tilapia) populations in Guangdong province of China using microsatellite markers. Biochem. Syst. Ecol., 55: 198-204, doi: 10.1016/j.bse.2014.03.035

Kiener A., 1963. Poissons, pêche et pisciculture à Madagascar. Centre technique forestier tropical, Nogent-sur-Marne, France, 160 p.

Lee W.-J., Kocher T.D., 1996. Microsatellites DNA markers for genetic mapping in Oreochromis niloticus. J. Fish Biol. 49: 169-171, doi: 10.1111/ j.1095-8649.1996.tb00014.x

Moreau J., 1988. Tilapia genetic resources for aquaculture. Madagascar. In: Proc. Workshop Tilapia Genetic Resources for Aquaculture (Ed. Pullin R.S.V.). International Center for Living Aquatic Resources Management, Bangkok, Thailand, 29-32, doi: 10.1016/0044-8486(86)90236-x 
Musapa M., Kumwenda T., Mkulama M., Chrishimba S., Norris D.E., Tuma P.E., Mharakurwa S., 2013. A simple Chelex protocol for DNA extraction from Anopehles sp. J. Vis. Exp., 71: 3281, doi: 10.3791/3281

Mwanja W.M., Kaufman L., Fuerst P.A., 2010. Comparison of the genetic and ecological diversity of the native to the introduced tilapiines (Pisces: Cichlidae), and their population structures in the Lake Victoria region, East Africa. Aquat. Ecosyst. Health Manag., 13: 442-450,doi: 10.1080/14634988.2010.527268

Ndiwa T.C., Nyingi D.W., Agnese J.F., 2014. An important natural genetic resource of Oreochromis niloticus (Linnaeus, 1758) threatened by aquaculture activities in Loboi Drainage, Kenya. PLoS One, 9: e106972, doi: 10.1371/journal.pone.0106972

Nei M., 1987. Molecular evolutionary genetics. Columbia University Press, New-York, USA, 512 p., doi: 10.7312/nei-92038

Oswald M.R., Ravakarivelo M., Mikolasek O., Rasamoelina H., de Verdal H., Bentz B., Pepey E., et al., 2016. Combining a comprehensive approach to fish-farming systems with assessment of their genetics - from planning to realization. In: Actes projet FSP PARRUR, Recherche interdisciplinaire pour le développement durable et la biodiversité des espaces ruraux malgaches. Application à différentes thématiques de territoire (éds Duchaufour H., et al.). MYE, Antananarivo, Madagascar, 219-267
Pritchard M.J.K.S., Donnelly P., 2000. Inference of population structure using microlocus genotype data. Genetics, 155: 945-959

Rakotoambinima S., Desprez D., David D.G., Bosc P., Le Roux Y., 2009. Caractérisation des environnements écologiques et socio-économiques de la production piscicole continentale à Madagascar. Cah. Outre Mer, 248 : 471-488, doi : $10.4000 /$ com.5778

Romana-Eguia M.R.R., Ikeda M., Basiao Z.U., Taniguchi N., 2005. Genetic changes during mass selection for growth in Nile tilapia, Oreochromis niloticus (L.), assessed by microsatellites. Aquac. Res., 36: 69-78, doi: 10.1111/j.1365-2109.2004.01185.x

Rousset F., 2008. GENEPOP'007: a complete re-implementation of the GENEPOP software for Windows and Linux. Mol. Ecol. Resour., 8: 103106, doi: 10.1111/j.1471-8286.2007.01931.x

Schuelke M., 2000. An economic method for the fluorescent labelling of PCR fragments. Nat. Biotechnol., 18: 233-234, doi: 10.1038/72708

Thai B.T., Pham T.A., Austin C.M., 2006. Genetic diversity of common carp in Vietnam using direct sequencing and SSCP analysis of the mitochondrial DNA control region. Aquaculture, 258: 228-240, doi: 10.1016/j. aquaculture.2006.03.025

Walsh P.S., Metzger D.A., Higuchi R., 1991. Chelex 100 as a medium for simple extraction of DNA for PCR-based typing from forensic material. Biotechniques, 10: 506-513, doi: 10.2144/000114018

\section{Résumé}

Ravakarivelo M., Pepey E., Benzie J.A.H., Raminosoa N., Rasamoelina H., Mikolasek O., de Verdal H. Variation génétique des populations sauvages et des stocks issus d'élevage de tilapia du Nil (Oreochromis niloticus) à Madagascar

Quatre stocks issus de piscicultures et quatre populations sauvages de tilapias du Nil (Oreochromis niloticus), espèce qui a été introduite initialement à Madagascar il y a soixante ans, ont été évalués pour leurs variations génétiques à partir de l'analyse de neuf locus microsatellites pour déterminer les niveaux de variabilité génétique au sein des populations et les relations génétiques entre ces populations. La diversité allélique recoupait celle qui a été rapportée dans d'autres populations africaines. II n'y avait ni évidence d'écart dans les fréquences alléliques attendues dans les conditions d'équilibre de Hardy-Weinberg ni de consanguinité dans les populations étudiées. Trois groupes génotypiques distincts ont montré trois introductions séparées (à partir d'Egypte et de l'île Maurice en 1956, et du Japon en 2011) et la présence de génotypes issus de plus d'un groupe dans une même population a fourni la preuve de mélanges. II y avait des différences significatives entre les populations qui ne provenaient pas du même milieu (sauvage ou d'élevage) ou qui n'étaient pas géographiquement reliées. De par leur diversité génétique, les populations sauvages pourraient être des ressources intéressantes dans la perspective d'un développement de la pisciculture du tilapia du Nil à Madagascar.

Mots-clés : Oreochromis niloticus, poisson, tilapia, population animale, variation génétique, structures génétiques, Madagascar

\section{Resumen}

Ravakarivelo M., Pepey E., Benzie J.A.H., Raminosoa N., Rasamoelina H., Mikolasek O., de Verdal H. Variación genética de las poblaciones silvestres y de los cultivos de tilapia del Nilo (Oreochromis niloticus) en Madagascar

La variación genética de cuatro poblaciones de cultivo y cuatro poblaciones silvestres de tilapia del Nilo (Oreochromis niloticus, introducida en Madagascar hace 60 años) fue evaluada con la análisis de 9 loci de microsatélites, con vistas a determinar los niveles de variabilidad genética dentro de las poblaciones y las relaciones genéticas entre las mismas. La diversidad alélica coincide con reportes referentes a otras poblaciones africanas. No se encontró evidencia de discrepancia en las frecuencias alélicas esperadas en condiciones de equilibrio Hardy-Weinberg ni de consanguinidad en las poblaciones estudiadas. Tres grupos genotípicos diferentes mostraron tres introducciones separadas (provenientes de Egipto y de Islas Mauricio en 1956, así como de Japón en 2011). La presencia de genotipos provenientes de más de un grupo en una misma población proporcionó la evidencia de mezclas genéticas. Se encontraron diferencias significativas entre las poblaciones que no provenían del mismo hábitat (salvaje o de cultivo) o que no estaban geográficamente relacionadas. Debido a su diversidad genética, las poblaciones salvajes podrían representar un valioso recurso con vistas al desarrollo de la piscicultura de tilapia del Nilo en Madagascar.

Palabras clave: Oreochromis niloticus, pescado, tilapia, población animal, variación genética, estructura genética, Madagascar 